\title{
Picocyanobacteria success in oligotrophic lakes: fact or fiction?
}

\author{
Cristiana CALLIERI* and John STOCKNER ${ }^{1)}$ \\ CNR -Istituto Italiano di Idrobiologia, Largo Tonolli 50, 28922 Pallanza, Italy \\ ${ }^{1)}$ Eco-Logic Ltd. 2614 Mathers Avenue, W. Vancouver, British Columbia, Canada \\ *e-mail corresponding author: c.callieri@iii.to.cnr.it
}

\begin{abstract}
Two approaches may be utilized to explain the predominance of picocyanobacteria (Pcy) in oligotrophic lakes: the analysis of their interannual evolution in one single lake and their relative importance in different lakes along a trophic gradient. Here we discuss results from field data on picocyanobacteria over several seasons from a deep oligotrophic subalpine lake - Lago Maggiore, and variables influencing their abundance. Comparing data from lakes along a trophic gradient, no simple relationship emerges between lake's trophic state and picocyanobacteria abundance and contribution to total phytoplanktonic biomass. That is, trophic state alone cannot explain the success/absence of picocyanobacteria that appear to be favored under P limitation, but seem more sensitive to grazing pressure and light. In some oligotrophic lakes, if light climate, grazing, and competition are favorable, picocyanobacteria can grow rapidly, out-compete competitors and become very abundant, but there are a host of factors that can influence the outcome of this competition, and ultimately influence Pcy success in lakes of all trophic types.
\end{abstract}

Key words: picocyanobacteria, trophic gradient, lakes

\section{INTRODUCTION}

Recently researches have been dealing with the picocyanobacteria (Pcy) contribution to total phytoplankton production and biomass in lakes along a trophic gradient (Petersen 1991; Stockner \& Shortreed 1991; Vöros et al. 1998) to seek a more comprehensive understanding of the ecological role of autotrophic picoplankton in freshwaters. Small unicellular algae in the size range of picoplankton have been found to out-compete the larger ones (e.g. Fenchel 1988; Søndergaard 1990) especially when nutrients are scarce as in the ultra-oligotrophic extreme of the gradient. One of the advantages of being small in nutrient impoverished environments is to be less limited by molecular diffusion of nutrients (Chisholm 1992). Small cells can take advantage of the small surface-to-volume ratio (Raven 1986), and in Pcy the prokaryotic structure gives them the lower costs for maintenance metabolism. These factors have been proposed as the main reason of their success under oligotrophic conditions (Weisse 1993). Nevertheless photosynthetic carbon uptake is not only affected by the availability of nutrients but by a host of variables, among the most important being light, temperature and phytoplankton community structure.

To better understand the ecological importance of natural populations of Pcy we used two approaches: 1) the analysis of the seasonal and vertical data sets from a large subalpine lake and 2) the comparison of different lakes along a trophic gradient. In this paper selected examples from both approaches are discussed in an attempt to better understand the interplay between biotic and abiotic variables and how they affect Pcy population abundance and production in lakes.

\section{ANALYSIS OF THE SEASONAL AND VERTICAL DATA SETS}

From the analysis of seasonal data sets one expects to find characteristic patterns in the temporal changes of the natural picoplanktonic assemblages in a lake. In turn, one expects to be able to relate these seasonal changes to the dynamics of the biotic and abiotic environment. But it is not that simple because the complexity of the pelagic ecosystems is related to the diversity in the community structure as modulated by intrinsic factors (basin morphometry, thermal structure, seasonal climate, etc.) and by human external influence such as the variation in the supply of nutrients (Harris 1980). Of course how the Pcy exploit this environmental variability is the result of evolutionary mechanisms and their interrelation with other phytoplankters of larger size.

We found an example of competition between Pcy and filamentous cyanobacteria in Lago Maggiore a large, deep oligotrophic lake in the Southern Alps (see de Bernardi et al. 1984 for details on Lago Maggiore). The same inverse relationship between Pcy and Anabaena has been reported by Stockner \& Shortreed (1988) in a British Columbia oligotrophic lake who concluded that it was due to allelopathy. In 1992 and 1993 in Lago Maggiore Oscillatoria limnetica and $O$. rubescens (now classified as Planktothrix rubescens) were the dominating filamentous cyanobacteria (Ruggiu et al. 1992, Panzani pers. com.) which can inhibit the growth of other phytoplankton species by producing microcystins (Feuillade 1994). These toxins are also important feeding deterrent against grazing by Daphnia (Kurmayer \& Jüttner 1999) who could in turn feed on 
Pcy causing a further reduction of their number. Analysing together the seasonal dynamics of pico- and filamentous cyanobacteria we noticed that the Pcy cell number decrease was in coincidence with the filamentous cyanobacteria increase similar to trends reported by Stockner \& Shortreed (1988). This fact becomes particularly evident when plotting the percentage density of the two cyanobacteria types (Fig. 1): it look like that the main regulatory factor of the seasonal fluctuations of Pcy abundance in the lake is the influence of nanoplanktonic filamentous cyanobacteria. The above pattern could be viewed as a case of overgrowth competition or of allelopathy, but competitive exclusion is never attained (Schoener 1983). Rather than a typical seasonal succession of different species we observe fluctuations with increases in Pcy when the filamentous forms disappear. The Pcy seasonal fluctuations may also depend from other factors like the selective protozoan grazing which could explain the momentary cell number decrease followed by a rapid increase. It is infact known that, also in the microbial loop, grazers regulate their prey presence thus influencing their seasonal oscillations (Weisse \& Schweizer 1991; Amblard et al. 1995).

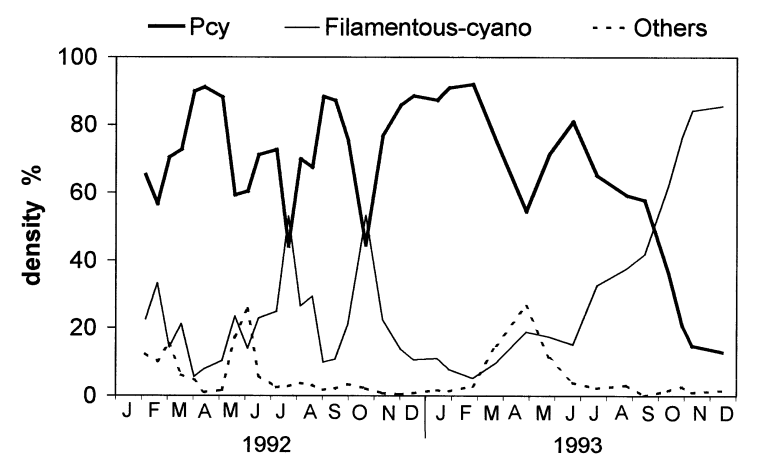

Fig. 1. Numbers of Pcy and filamentous cyanobacteria cells and other phytoplankton expressed as percentage of the total phytoplanktonic counts in Lago Maggiore.

As first noted by Harris (1980), the growth rate of mixed phytoplankton assemblages is dependent on the size spectrum of their cells. The cell size changes could be the strategy of the community to exploit environmental variability. In such a 'size and function' framework the ecological significance of Pcy and their success may be evaluated analysing Pcy evolution during the re-oligotrophication of Lago Maggiore. In this lake the total phosphorus gradually decreased from $1978\left(35 \mathrm{~g} \mathrm{l}^{-1}\right)$ to $1998\left(7 \mu \mathrm{g} \mathrm{l}^{-1}\right)$ at winter mixing, but chlorophyll values visibly dropped only after 1987 (Ruggiu et al. 1998) and the photosynthetic efficiency increased in 1994 (Bertoni et al. 1998). Along with the phytoplankton community changes a parallel trend towards the increase in abundance and production of picocyanobacteria was observed from 1992 to 1998 (Fig. 2). Since 1995 it has been possible to see both a spring and a late summer peak of abundance, separated by a low density period in June and July. In 1998 the spring peak appeared later (in June) and the maxima were reached in September. The spring peak was almost exclusively due to single cells of Pcy (Cyanobium sp.) whereas in late-summer/autumn the variety of morpho-types increased and aggregates and colonial forms played a significant role in the cyanobacterial population structure (Passoni \& Callieri 1999). We think that this recurrent, bimodal, seasonal cycle may be the result of clone succession with changing morpho-types suggesting a possible adaptive response of Pcy populations to the seasonally variable physico-chemical factors of Lago Maggiore (Stockner et al. 2000).
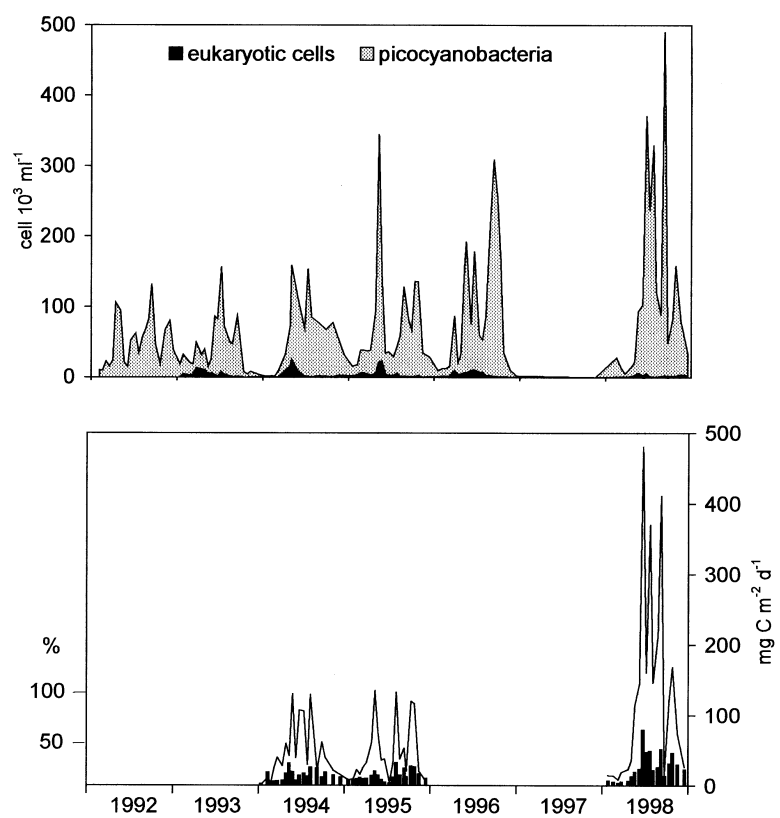

Fig. 2. Annual and interannual variation of Pcy abundance (upper panel, cells $10^{3} \mathrm{ml}^{-1}$ ) and production (lower panel, line:

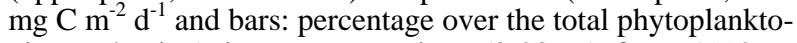
nic production) in Lago Maggiore $(0-20 \mathrm{~m})$ from 1992 to 1998.

Over the six year study from 1992 to 1998 the trend toward the increase of Pcy cell number and production demonstrate the success of this algal fraction in the recovered lake. In this period the percentage of the Pcy annual production passed from 10 to $21 \%$ of the total phytoplanktonic production. In this context the increased importance of Pcy could be related to the changes in the pelagic food-web observed during the long-term lake's evolution which were triggered by the in-lake $\mathrm{P}$ decrease.

The temporal scale is tightly coupled to the spatial scale and the study of the seasonal variability of picoplankton cannot be correctly interpreted without a good description of the cell response to the external forces which change within the water column. One of the cau- 


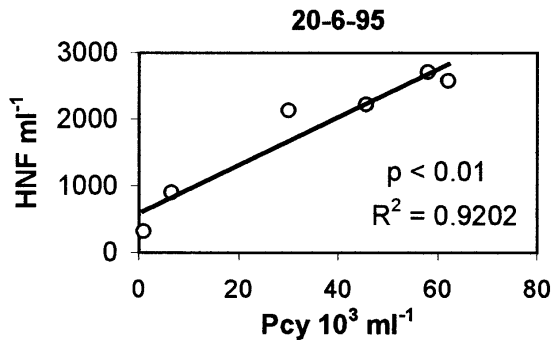

12-9-95

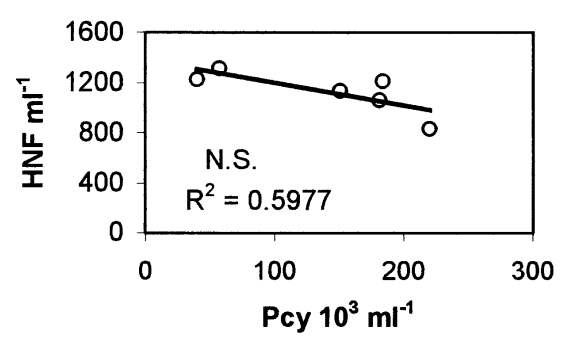

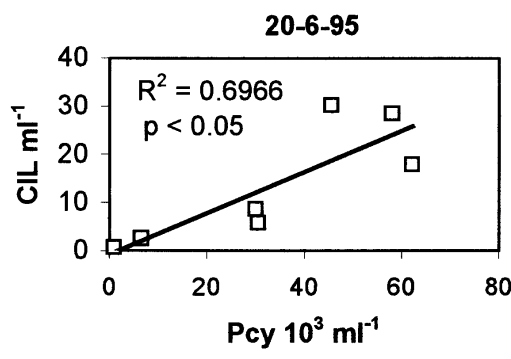

12-9-95

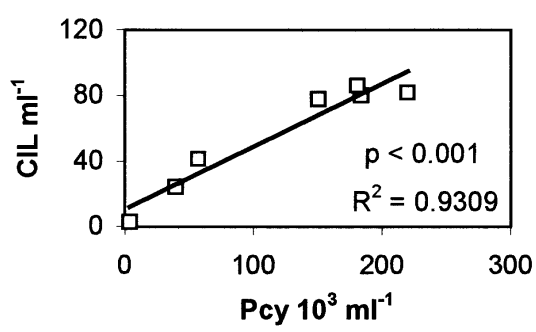

Fig. 3. Relation between Pcy and protozoa abundance (HNF and Ciliates) in the water column during summer stratification in Lago Maggiore. ses of the vertical heterogeneity may be the prey-predator interaction which is often evidenced by the existence of a correlation in the vertical distribution of consumers and their possible food (Amblard et al. 1995). The study of the vertical distribution of Pcy in Lago Maggiore has brought good evidence of their tight connection with their principal predators: heterotrophic nano-flagellates (HNF) and ciliates. Here we show two examples which illustrate the relation between Pcy and $\mathrm{HNF} /$ ciliate abundance along the water column during summer stratification (Fig. 3). The ciliate community, in June, is dominated by oligotrichs whereas in August scuticociliates prevail (Callieri 1999). From figure 3 in June both ciliates and HNF are more abundant at the depth where there are more Pcy food and in both cases the correlation is positive and significant $(p<0.01$ for HNF, $\mathrm{p}<0.05$ for ciliates). The vertical distribution reported elsewhere (Passoni et al. 1997) have shown that the presence of ciliates and $\mathrm{HNF}$ at $13 \mathrm{~m}$ reduced the usual Pcy peak in the metalimnion. Besides, these obsevations were corroborated by direct uptake measurements, showing that in Lago Maggiore the carbon flux from Pcy to protozoa ranged between 0.33 to $1.22 \mu \mathrm{g} \mathrm{C}$ $\mathrm{l}^{-1} \mathrm{~h}^{-1}$, corresponding to a removal from 10 to $40 \%$ of Pcy cells (Callieri et al. 1999). In September both Pcy and ciliates increase and the scuticociliates had an uptake rate of $2.5 \mathrm{Pcy} \mathrm{cil}^{-1} \mathrm{~h}^{-1}$ which correspond to $60 \%$ removal of Pcy by the whole ciliate community (unpublished data). HNF on the other hand showed no significant relation with Pcy abundance, but the peak of Pcy along the profile corresponds to the decline of HNF (Passoni et al. 1997). This example from Lago Maggiore, of the dynamics in the vertical profile of Pcy and their consumers, provides further evidence that the presence of the predators is related to the abundance of their prey and that in some particular conditions (as at certain depths) protozoa can even control the population size of Pcy.

Grazing rates are usually balanced by comparable growth rates (Weisse 1993), and can have a pronounced diel pattern related to prey size. If and to what extent the grazing activity is growth rate dependent, and which are the more important regulating mechanisms involved, still remains a matter of conjecture. Nonetheless, this is an important issue in the study of picoplanktivory and some authors have addressed their efforts at first to measure directly in situ grazing and growth rates to see if in fact they are in balance, and how their relative importance varies with changing environmental conditions (Weisse 1995; Nagata et al. 1996). It is now possible to conclude that Pcy grazing losses seem to show large seasonal variability and are tightly coupled and sometimes in balance with Pcy growth rates.

\section{PICOCYANOBACTERIA AND TROPHIC GRADIENT}

The second approach we used is based on the studies of different lakes along a trophic gradient that includes high altitude clear lakes, deep large sub-alpine lakes, large shallow lakes and small reservoirs or fish ponds (Vörös et al. 1998). The trophic gradient approach can be particularly useful when examining the influence of resource availability on Pcy growth and abundance.

By examining a large trophic gradient investigating on 32 deep and shallow lakes, Vörös et al. (1998) asserted that the relation between Pcy abundance / contibution to total phytoplanktonic biomass and lake trophic state cannot be fully explained with a simple model such as that one proposed by Stockner (1991). Across such a trophic gradient chlorophyll concentrations ran- 
ged between 0.2 and $390 \mu \mathrm{g}^{-1}$. The relative contribution of Pcy can be more than $70 \%$ of the total phytoplankton biomass in lakes with chlorophyll below $10 \mu \mathrm{g}$ $\mathrm{l}^{-1}$, whereas above the threshold of $100 \mu \mathrm{g} \mathrm{Chl} \mathrm{l}^{-1}$ the contribution of the Pcy fraction does not exceed $10 \%$. Using the extensive data base of Vörös et al., (1998) we have attempted to indicate a general trend in a graphical model, illustrating the areas of possible occurrence of Pcy numbers and their contribution to total phytoplankton biomass $(\mathrm{Chl})$ within a broad trophic gradient (Fig. 4) (from Stockner et al. 1999). The new concept is that there is not a linear relationship which drives the Pcy presence and importance in lakes, rather the success of Pcy in oligotrophic lakes is not a certainty but a potentiality. In some oligotrophic lakes with extremely low ambient nutrient concentrations, if conditions like light climate, grazing impact and competition are favorable, Pcy can out-compete all other larger autotrophic algae.

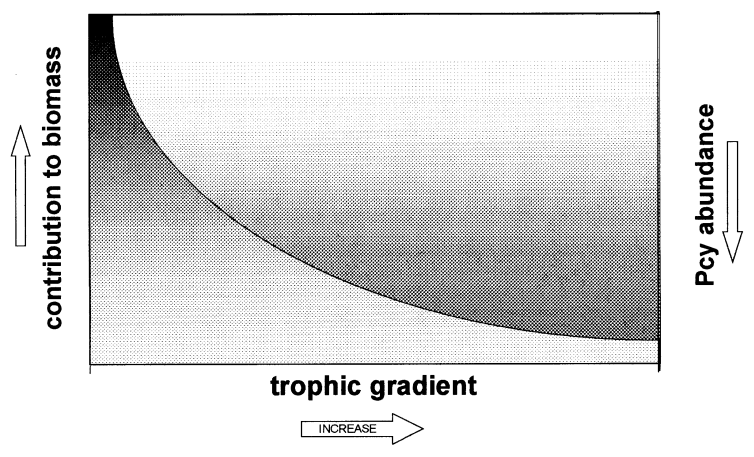

Fig. 4. Schematic draft of the areas of occurrence of Pcy numbers and of their relative contribution to total phytoplanktonic biomass (chlorophyll- $a$ ) along a trophic gradient (from Stockner et al. 2000, modified).

In conclusion the success of the Pcy in oligotrophic lakes may be regarded better as a fact than as a fiction but the trophic state alone is only a conditio sine qua non Pcy can prevail in the phytoplanktonic community.

\section{REFERENCES}

Amblard, C., J.F. Carrias, G. Bourdier \& N. Maurin. 1995. The microbial loop in a humic lake: seasonal and vertical variations in the structure of the different communities. Hydrobiologia, 300/301: 71-84.

Bertoni, R., C. Callieri, G. Morabito, M.L. Pinolini, A. Pugnetti. 1998. Quali-quantitative changes in organic carbon production during the oligotrophication of Lake Maggiore, Italy. Verh. int. Ver. Limnol., 26: 300-304.

Callieri, C. 1999. Carbon flux from picocyanobacteria to ciliates in a subalpine lake. Verh. int. Ver. Limnol., 27: (in press).

Callieri, C., S. Henimaa, S. Passoni. 1999. Interazioni protozoi-picocianobatteri: misure di grazing nel Lago Maggiore. Atti della Associazione Italiana di Oceanologia e Limnologia, 13(2): (in press).

Chisholm, S.W. 1992. Phytoplankton size. In: Falkowski, P.G. \& A.D. Woodhead (Eds), Primary productivity and bio- geochemical cycles in the sea. Plenum Press, N.Y: 213237.

de Bernardi, R., G. Giussani \& E. Grimaldi. 1984. Lago Maggiore. In: Taub F.B. (Ed.), Lakes and Reservoirs, Elsevier, Amsterdam: 247-266

Fenchel, T. 1988. Marine plankton food chains. Ann. Rev. Ecol. Syst., 19: 19-38.

Feuillade, J. 1994. The cyanobacterium (blue-green alga) Oscillatoria rubescens D.C. Arch. Hydrobiol. Beih. Ergebn. Limnol., 41: 77-93.

Harris, G.P. 1980. Temporal and spatial scales in phytoplankton ecology. Mechanisms, methods, models and management. Can. J. Fish. aquat. Sci., 37(5): 877-900.

Kurmayer, R., F. Jüttner. 1999. Strategies for the co-existence of zooplankton with the toxic cyanobacterium Planktothrix rubescens in Lake Zürich. J. Plankton Res., 21(4): 659-683.

Nagata, T., K. Takai, K. Kawabata, M, Nakanishi \& J. Urabe. 1996. The trophic transfer via a picoplankton-flagellatecopepod food chain during a picocyanobacterial bloom in Lake Biwa. Arch. Hydrobiol., 137: 145-160.

Passoni, S. \& C. Callieri. 1999. Picocyanobacteria single forms, aggregates and microcolonies: survival strategy or species succession? Verh. int. Ver. Limnol., 27: (in press).

Passoni, S., C. Callieri \& S. Heinimaa. 1997. Dinamiche di distribuzione del picoplancton autotrofo nel Lago Maggiore. In: Albertelli, G., A. De Maio \& M. Piccazzo (Eds), Atti del $12^{\circ}$ Congresso AIOL. vol. 1: 109-118.

Petersen, R. 1991. Carbon-14 uptake by picoplankton and total phytoplankton in eight New Zealand Lakes. Int. Revue ges. Hydrobiol., 76: 631-641.

Raven, J.A. 1986. Physiological consequences of extremely small size for autotrophic organisms in the sea. In: Platt, T. \& W.K.W. Li (Eds), Photosynthetic picoplankton. Can. Bull. Fish. aquat. Sci., 214: 1-70.

Ruggiu, D., G. Morabito, P, Panzani \& A. Pugnetti. 1998. Trends and relations among basic phytoplankton characteristics in the course of the long-term oligotrophication of Lago Maggiore. In: Alvarez-Cobelas, M., S. Reynolds, P. Sanchez-Castillo \& J. Kristiansen (Eds), Phytoplankton and trophic gradients. Kluwer Academic Publisher. Hydrobiologia, 369/370: 243-257

Ruggiu, D., P. Panzani \& G. Morabito. 1992. Indagini sul fitoplancton. In: Istituto Italiano di Idrobiologia C.N.R. (Ed), Ricerche sull'evoluzione del Lago Maggiore. Aspetti limnologici. Programma quinquennale 1988-1992 (Campagna 1992) e rapporto quinquennale. Commissione Internazionale per la protezione delle acque italo-svizzere: 65-68

Schoener, T.W. 1983. Field experiments on interspecific competition. Amer. Nat., 122: 240-285.

Søndergaard, M. 1990. Picophytoplankton in Danish lakes. Verh. int.Ver. Limnol., 24: 609-612.

Stockner, J.G. 1991. Autotrophic picoplankton in freshwater ecosystems: the view from the summit. Int. Revue ges. Hydrobiol., 76: 483-492.

Stockner, J.G., C. Callieri \& G. Cronberg. (2000). Picoplankton and other non-bloom forming cyanobacteria in lakes. In: Whitton, B. \& M. Potts (Eds), Ecology of Cyanobacteria: Their Diversity in Time and Space. Kluwer Academic Publishers: (in press).

Stockner, J.G., K.S. Shortreed. 1988. Response of Anabaena and Synechococcus to manipulation of nitrogen:phosphorus ratios in a lake fertilization experiment. Limnol. Oceanogr., 33: 1348-1361.

Stockner, J.G. \& K.S. Shortreed. 1991. Autotrophic picoplankton: community composition abundance and distribution across a gradient of oligotrophic British Columbia and Yukon Territory lakes. Int. Revue ges. Hydrobiol., 76: 581-601. 
Vörös, L., C. Callieri, K. Balogh \& R. Bertoni. 1998. Freshwater picocyanobacteria along a trophic gradient and light quality range. In: Alvarez-Cobelas, M., S. Reynolds, P. Sanchez-Castillo \& J. Kristiansen (Eds), Phytoplankton and trophic gradients. Kluwer Academic Publisher. Hydrobiologia, 369/370: 117-125.

Weisse, T. 1993. Dynamics of autotrophic picoplankton in marine and freshwater ecosystems. In: Jones, J.G. (Ed),

Received: January 2000

Accepted: April 2000
Advances in microbial ecology, 13. Plenum Press: $327-$ 370.

Weisse, T. 1995. The annual cycle of heterotrophic freshwater nanoflagellates: role of bottom-up versus top-down control. J. Plankton Res., 13: 167-185.

Weisse, T. \& A. Schweizer. 1991. Seasonal and interannual variation of autotrophic picoplankton in a large prealpine lake (Lake Constance). Verh. int. Ver. Limnol., 24: 21825 . 